\title{
TÜRK TARIHINDE ERMENILER
}

\author{
Dr. Ithan AKBULUT*
}

\section{Ermenilerin Kökeni}

Ermenilerin kokeni hakkında Ermeni tarihçiler arasında dahi bir birlik yoktur. Bu konuda çeşitli gơrüşler ileri sürülmüştür. Bir menkıbeye göre Ermeniłer Nuh'un torunu olan Hayk'tan gelmektedirler. Bu görüs sahipleri Nuh'un gemisi Ağn Dağı'na oturduğundan Ermenilerin ana yurdunun Doğu Anadolu Bölgesi olduğunu iddia ederler. Bir kısım tarihçiler Ermenilerin kökenini Urartular'a dayandırırken bir kısmı Ermenilerin bir turan ırkı olduğunu iddia etmektedirler. Bir kısım tarihçiler ise, Ermenilerin Balkan kőkenli ve Trak-Frig soyuna ait olduklannı soylerler.

Doğu Anadolu'daki birtakım vilayetlerimizi içine alan ve Ermenistan denilen bolgenin bu ismi nereden aldığı bilinmemektedir. Yalnız bilinen birşey vardır ki bu da, bu bolgenin Ermenistan olarak adlandırılmasının nedeni, üzerinde Ermenilerin yasaması de ğildir. Ermeniler kendilerini "Hayk" diye isimlendirir ve ülkelerine "Haystan" derken, onların yaşadı̆̆ı topraklara neden Ermenistan denilmiş olduğu hakkında kaynaklarda belgelenmiş bir kayıt yoktur ${ }^{1}$.

Bugün Ermeni denilen topluluğun M.Ö. IV. yüzyıldan beri bu bőlgede yaşadiklan sanılmaktadır. Bunlar birbirlerine vatan hissi ile değil, gelenekleriyle, konuştuklan dille ve dinleriyle bağhlıdular²

*Diyarbakır Devlet Güvenlik Mahkemesi Hakimi.

1GORUN, K. Ermeni Dosyasi. Ankara, 1985, s. 10.; ETHEMOGLU, M. Ermeni Teroranon Kısa TArihi, Diyarbakur, 1987, s. 2.; EROĞLU, V., Ermeni Mezalimi. Sebil Yayınevi, Istanbul, 1973, s. 15.; Ermeni Meselesinde daha geni§ bilgi için Bk. M.K. OKE. Ermeni Meselesi. 1914-1923, Istanbul, 1986. .

2KAŞGARLI. M. A., Ortaçă̆ Ermeni Tarihleri Kritiởi. Tarih Boyunca Turklerin Ermeni Toplumu ile Ilişkileri Sempozyumu, Ankara, 1985, s. 329.; ETHEMOĞLU, M., age. s. 4 
Ermeniler Osmanlı Imparatorluğu'nda genellikle ticaret ve san'atla ựraşmışlardı. Dini konularda Babı Ali'ye karşı sorumlu olan patrike bağlıydılar. Ermeniler devlet hizmetlerinin her kademesinde görev almaktaydılar ${ }^{3}$.

1839 yılında Gülhane Hattı Hümayunu ile tüm Osmanlı halkına Müslüman Hrıstiyan ayırımı yapılmaksızın tam bir eşitlik içerinsinde mal, can ve namus güvenliği sał̆lanmıştı.

19 Yüzyılın sonlarında yabancı yazarlara göre Osmanlı Imparatorluğunda $1.300 .000-1.500 .000$ Ermeni yaşamaktaydı ${ }^{4}$. Osmanlı Imparatorluğu kaynaklanna göre ise 1.160 .000 Ermeni yaşamaktaydı. Ermeni kaynaklarda nufus daha fazla gősterilmektedir. Bunun amacı ózellikle doğu illerimizde Ermeni nufusunu müslüman Türk nufusundan daha çok oldư̛̆unu gơstermek suretiyle buralarda bağımsızlık elde etmekti.

Sonuç olarak şunu sőyliyebiliriz: 19. yüzyıl sonu ile 20. yüzyıl başlarında Osmanlı Imparatorlựu topraklarında yaşayan Ermeniler, toplam nufusun ancak \%13'ünủ oluşturmaktaydı ve hiçbir zaman, hiçbir bölgede çoğunluğu oluşturmamışlardır.

\section{Ermeni Sorununun Nedenleri.}

Uzun yıllar birarada birlik, beraberlik içinde yaşayan Türkler ve Ermeniler arasında neden tatsız bu olaylar olmuştur? Millet-1 Sâdıka olarak Osmanlı Sarayı'nın güvenini kazanmıs Ermeni halk neden isyan etmiştir. Bunun gerçek nedenlerini araşurmak gerekir. bu nedenleri şu şekilde sayabiliriz:

a. Ermeni Kilisesi: Rusların, Osmanlı Imparatorluğg'nu yıkarak, Bizansı ihya etmek fikri her zaman vard. Ermeni Kilisesi boyle bir durumda Rusya'nın Ermeni Gregoryan Kilisesini içinden eriteceğini ve bağımsız kimlił̧ini yok edeceğini düşünüyordu. Zaten Ermeni Kilisesi Bizans Kilisesinden bağımsızlı̆̆ını sağlamak için ayrılmışı. Şimdi bu bağımsızlıği korumak gerekirdi. Bunun çaresi de Osmanlı

${ }^{3}$ ANADOL, C., Tarihin Işı̆̌̆ında Ermeni Dosyası, Istanbul. 1982, s. 58.; SEVIM, "Tarihte ilk Tưrk-Ermeni ilişkileri, 1018 yılında Selçuklular tarafından başlatılmı§ ve yaklaşık ự yüzyıl gibi uzun bir săre devam etmiştir" demektedir. Bk. Ali SEVIM, Selçuklu-Ermeni Ilişkileri, T.T.K.Y., Ankara, 1983, s. 7; Ermeniler kamu hizmetlerinde de onemli mevkiler elde etmişlerdir. Osmanlı tarihi Ermenilerden 29 Paşa, 22 BAkan, 33 Milletvekili, 7 Buyükelçi, 11 Başkonsolos ve Konsolos, 11 Universite Ögretim Uyesi ve 41 Yaksek rutbeli memur kaydetmektedir. Zikreden ETHEMOGLU, M. age. s. 6

${ }^{4}$ URAS, E. age. s. 133.; GURUN, Ingiliz gezgin Lynch'in Osmanlı Imparatorluğundaki Ermeni nufusunu 1.325.246 olarak belirttiğini soylemektedir. Bk. GURON, K. age. s. 92.; URAS da Rolan Jakmen'in Osmanlı Imparatorluğu'nda 1.330.000 Ermeni yaşadığın belirttiğini ifade etmektedir Bk. URAS, e., age. s. 134.; Almanya'da yaymlanan "Geo" isimli derginin yazarlanndan Wolfgang SCHRAPS'ın bir makalesinde verdił̧i bilgiye göre, 1915'ten ónce Ermeni nufusunun 1.200.000 olduğu iddia edilmektedir. Bknz. "Geo" Das Neue Bild der Erde, Nr. 3, Marz 1986, C. 2498 E, "Auf der Suche nach dem verschwundenen Volk".; Osmanlı Imparatorluğu'nda Ermeni nufusu hakkında genis bilgi için Bk. MAZICI, N., Belgelerle Uluslararası Rekabette Ermeni Sorunu'nun Kokeni, 1878-1918, Istanbul, 1987, s. 60-62.; ETHEMOǴLU, M., age. s. 16. 
Imparatorluğu'na bağ̆ı ơzerk bir Ermenistan Devletinin kurulmasıydı. Ermeni Devleti fikri Ermeni topluluğundan değil Ermeni kilisesinden çıkmışur ${ }^{5}$.

b. Din Faktörü: Türklerle Hristiyanların ilişkilerinde din fakıơru her zaman onemli olmuştur. Türklerin egemenliğine aldığı uluslara karşı gősterdiği dini hoşgớa hiçbir zaman takdir edilmedi, haçl zihniyeti bir türlü sona ermedi.

Hristiyan Rusya'nın, yine bir Hristiyan olan Polonya'ya yapuklan eziyeti, zulûmu görmeyen başta Ingiltere, Fransa ve Amerika olmak üzere Avrupa Devletlerinin Müslüman Türkiye'deki Ermenilerin koruyuculuğuna kalkışmalan ancak din fakıơrüyle açulanabilir.

c. Misyonerlerin Çalışmass: Protestan misyonerler ilk olarak 1804 yılında Türkiye'ye gelerek Izmir'den Anadolu içlerine dağılmışlardır. Amerikan misyonerleri de 1814 yılından sonra gelmeye başlamışlardır Misyonerler başı Dơ̆u Kilisesi ve Müslümanlara yőnelik olarak iki yönlü çalışıyorlardı. Misyonerler Müslümanlar arasında etkili olamayınca etkinliklerini Doğu Kilisesi üzerinde yoğunlaşurdılar. Doğu Kilisesinde Ermenilerden başka Grekler, Bulgarlar vs.'de bulunuyordu. Protestan misyonerler Ermenileri Protestan Kilisesine kazandırdılar. Ingiltere'ninde araya girmesiyle Osmanlı Hükümeti Protestan Kilisesine izin verdi ve Protestan Ermeni toplumu boylelikle oluştu. Misyonerler, "yasa hükümlerine gerek kalmadan, Allaha inanarak kurtulmak" seklindeki standart doktrinlerini savunuyor ve ogretiyorlard ${ }^{6}$. Misyonerlerin faaliyetleri isyanlan desteklemese bile isyanlann zeminin hazırlanmasında ónemli rolü olmuşur.

d. Büyük Devletlerin Tutumu: $1870^{\prime}$ lerde batulı devletlerin politikasinda Ermenilerin yeri yoktur. Batulı Devletlerin Ermeniler için bir dosya tutmalan bu tarihten sonra olmuştur. Osmanlı Imparatorluğu karşısında yüzyıllardır toprak kaybeden Avusturya en ufak bir harekette, toprak kazanabilmek umuduyla Rusya'nin yaninda yer alıyordu. Rusya'nın Türkiye'ye karşı tutumu ơteden beri belliydi. Istanbul'u alıp Bizansı yeniden ihya etmek. Aynca Ruslar güneye sıcak denizlere inmek için Anadolu'nun doğusunda tampon bir bölge oluşturmak istiyordu. Bu emellerini gerçekJeştirme için Osmanlı Devleti bünyesinde yaşayan Ermeniler bulunmaz fırsatı. Rusya Küçük Kaynarca antlaşmasına Osmanlı Imparatorluğu'nda yaşayan Hristiyan tebanın haklannı koruyacă̆ına iliş̧in bir madde koymuştur. Rusya'nın kullandığı taktik şuydu; Osmanlı Imparatorluğu içindeki azınlıklan kışkırtma ve azmetuirme suretiyle isyana geçirmek, sonra da onlann haklanın korumak bahanesiyle savaş açıp, hristiyan unsurlann da arkadan vurmasıyla Imparatorluğu içten çökertip emellerine kolay yoldan ulaşmak.

1875 yllında KAiser Wilhelm, François Joseph ve II. Alexandre biraraya gelerek Osmanlı Imparatorluð̧u'ndaki olası bir azınlık isyanında Osmanlı Imparatorlư̧u'na yardım etmiyecekleri yolunda "Ademi müdahale" ilkesini benimsemişlerdir?. Buna karșin 1877-78Osmanlı Rus Savaşı, $1875^{\prime}$ 'te Hersek'te başlayıp, 1876'da Bulgaristan'a ve Surbistan'a yayılan isyanların basunlması sonucu Rusya'nın asiler lehine mildahslesiyle başlamısur8.

$5_{\text {GURUN, K. age. s. } 30 .}$

${ }^{6}$ GURON, K. age. s. 43.

$7_{\text {GURON, K. age. s. } 77 .}$

${ }^{8}$ GURON. K. age. s. 78. 
Osmanlı - Rus Savaşında Ingiltere, Rusya'ya karşı Osmanlı Imparatarluğu'nun yanında yer aldı. Ingilizlerin bu politikası Gladstone'un Başbakan olmasına kadar bir asır devam etti. Berlin Kongresi'nden sonra iktidara gelen Gladstone hükümeti Ermeni bağımsızlık hareketinde Rusya'nın yanında yer aldı. Ingiltere'nin bundan beklediği amaç Emenilere bağımsızlığı kendisinin bahşettiği inancını vererek kendilerine minnettar bir devlet yaratmak, bunun nihai amacı da Ruslann sıcak denizlere inmelerini onlemekti. Ingiltere Türkiye'de açtı̆̆ı din ve ę̆itim kurumlarıyla ợ planda Ermeni kültürünü ele almış, Ermenilerin ulusal duygulannı kışkırtmışırı?

\section{Ermeni Sorununun Doğuşu}

1856 tarihine kadar Osmanlı tabiyetindeki Ermenilerle halkın veya hükümetin bir çauşması, çelişmesi vuku bulmamışur. Bu tarihten osnra Ermenilerin kendi aralanında ve patrikanenin de içinde bulunduğu iç çekişme devam etmekteydi. $1875^{\prime} t e$ Hersek'te isyan çıkıp genişleyince ve büyük devletler olaya kanışıp buralarda yenileştirme ve iyileştirme yapılmasını isteyince Ermeni Kilisesi bu fırsattan istifade ederek Doğu illeri için özerklik olabileceğini düşünerek çaba sarfetmeye başladı.

Hersek ve Bulgaristan olaylan nedeniyle Istanbul'da yapilacak olan konferansta kendi durumlarının da görüşülmesi için büyük devletlere muhtıralar yollandı. Ama bu toplantıda Ermeni konusu görüşülmedi. 24 Nisan 1877 günü Rusya Osmanlı Imparatorluğu'na savaş açınca Ermeniler özerklik ümitlerini bu savaşa bağladılar. 1877 78 savaşını Osmanlı Imparatorluğu tek başına sürdürmüs ve çok ał̆ır koşullarda, 3 Mart 1878 'de Ayastafonos (Yeşilkðy) Antlaşmasııı imzalamak zorunda kalmışur. Ermenilerin büyük çabası sonunda antlaşmaya 16. maddede ifadesini bulan hüküm konulmuştu. Bu maddeye göre; Ermenistan diye bir devlet vardı, bunlanın yeni düzenlemelere ihtiyaçlan vardı, bunlar Kürtler ve Çerkezler tarafından tehdit ediliyorlardı ve güvenlikleri zaman geçirilmeksizin saģlanacaktı. Bu antlaşmayla Ermeni Sorunu ilk defa uluslararası bir antlaşmaya girmiş oldu ${ }^{10}$. Bu antlaşma yürürlüğe girmedi. Antlaşmanın Ruslan üstün bir duruma getirdigini gören Avrupa Devletlerinden başta Ingiltere olmak Üzere Fransa, Almanya ve Avusturya'nın zorlamalarıyla Rusya Berlin Kongresi'ne gitmek zorunda kaldr. Berlin Kongresi'nde (13 Haziran - 13 Temmuz 1878), Osmanlı Imparatorluğu'na daha az vecibeler yüklenen yeni bir antlaşma yapıldı. Bu antlaşmanın Ermenilerle ilgili 61. maddesinde Osmanlı Imparatorlugu'nun, "Ermeni nufusu bulunan illerde yerel koşulların gerektirdiği düzenleme ve yenilikleri zaman geçirmeksizin yapacağı̆, Emenilerin huzur ve güveninin sağlanacağ dił̌er devletlerin de alınan ónlemleri kontrol edeceģi" hükmü yer alıyordu.

\section{Ermeni Komitaları:}

Ermeniler Doğu Anadolu'da bağımsız bir devlet kurmak amacıyla Avrupa ve Amerika'da ơrgütlenerek yoğun bir propaganda eylemine giriştiler. Bulundulan ülke politikasına ters düşmemek koşuluyla Türkiye aleyhine her türlä propagandayı

\footnotetext{
9SAKARYA, 1., Belgelerle Ermeni Sorunu, Ankara, 1984, s. 64.

10 ARIPINAR, E. Ermeni Meselesi, Hayat Tarih Mecmuası, Sayı 7, 1 Ağustos 1865, s. 72; MAZICI, N., age. s. 13-15.
} 
yapıyorlardı. Birçok dernek ve klüp kurmuşlar, birçck gazete çıkaruyorlardı. Derneklerden en etkin olanlan Hınçak ve Taşnaksutyun dernekleridir.

Hunçak (Çan sesi) Demeł̧i 1877'de Cenevre'de Rus uyruklu Avedis Nazarbekyan ve kendi gibi Rus kőkenli olan arkadaşlan tarafından kurulmuştur. Bunlar Karl Marx'ın ilkelerini temel alarak benimsemişlerdir. 1890 yılında merkezi Istanbul'da olmak üzere Anadolu'da birçok şube açtılar. Dernek mensuplan bağımsız ve Sosyalist bri Ermenistan'ın ancak tedhiş yoluyla kurulabileceğine inanıyorlardı ve bu yolda eylemlerde bulunuyorlardı. Daha sonralan dernek mensuplan arasında anlaşmazlık çıkı, birbirlerine düşüller ve demek dağıldıl1.

Hinçakların faaliyetleri hakkında Trabzon'dan Ingiliz Konsolosu, elçi Sir Currie'ye 28 Ekim 1895'te şరyle yazıyordu: "Hınçaklar dışarıdan idare ediliyorlar ve kendileri tamamen emniyet içinde bulunduklan halde Türkiye'deki urkdaşlanna hayatı dayanılmaz hâle getiriyorlar. Amaçları, Hristiyanlara karşı kışkırtmak ve katliamlar çıkartarak memleketi dehşet içinde bırakmakur. Bütün dünyaca bilinmelidir ki bu orgütün anarşik bir yapisı vardir" 12 .

Taşnaksutyun 1890 yılında Tiflis"te kurulmuş ve ihtilalci federasyondur. Amacı çeşitli çeteleri çausı alunda toplamak ve Rusya'dan Türkiye'ye geçecek çetelere yardımcı olmakıı. Komite yayınladığı bir bildiride Siyasi ve ekonomik bağımsızlıklanını elde etmek amacıyla Osmanlı Imparatorluğu'na savaş açmak için Ermenileri birleşmeye çă̌̆ırıyordu ${ }^{13}$.

Komite 1892 yılında ilk toplantusını yapu ve bu toplantuya Türkiye'de açuklan şubelerin bulunduğu illerden delegeler katıldı. Bu toplantıda, "Türkiye'de isyan çıarulması, hainlere, casuslara, hafiyelere, devlet adamlarina suikastlar hazırlanması ve silah gơnderilmesi, silah kullanma eğitimlerinin yapılması bütün Ermeni ulusunun ozellikle gençlerin isyana hazır olmaları" kararlan alındı14. Bu komite 3. Kolordu'yu yıllarca uğrasırmıs sınırdaki kbylere baskınlar yapmıs, katliam hareketleri yağma eylemleri yapmıştır. Robert College Müdürü Dr. Hamlin, Boston'daki bir dergiye gơnderdiği mektupta Hınçak thuilâl Partisi'nin "Rus alunı ve zekası ile idare edildiģini" yazmışır 15 .

\section{Meşrutiyetin Ilanına Kadar Ermeni Isyanları.}

Türklerle Ermeniler arasındaki düşmanlık Türkler' in Ermenilere tecavïzülnden deģil Ermeni Taşnaksutyun ve Hınçak Komitelerinin Ermeni halkı silahlandırması ve bağımsızlıklarını ilan etmek amaciyla yurdun birçok yerinde isyan çıkarmalanyla doğmuştur. Bunları kışkırtup silahlandıran ise Rusya ve Ingiltere'dir.

${ }^{11}$ KURAN, E., Ermeni Meselesinin Milletlerarası Boyutu, Tarih Boyunca Türklerin Ermeni Toplumu ile llişkileri Sempozyumu. Ankara 1985, s. 20.; ETHEMOĞLU, M. age. s. 20; MAZICI, N., age. s. 31-32.

12 URAS, E., age. s. 442.

13 SAKARYA. 1., age. s. 88.; ETHEMOǦLU, M., age. s. 21 .; MAZICI, N., age. s. 32-33.

14 ANADOL, C., age. s. 98.

15 ANADOL, C.,age. s. 100. 
1877-78 Osmanlı - Rus Savaşından sonra Ermeniler silahlanmaya başladılar. Ermeniler, Sason'da, Erzurum'da, Van'da, Zeytun'da isyanlar çıkartular. Istanbul'da Osmanlı Bankası'nı basıp bombaladılar. 21 Mayıs 1905'te padişah II. Abdülhamit'e karşı basarısız bir suikastta bulunacak kadar ileri gittiler.

\section{Meşrutiyetin flanından Sonraki Ermeni Hareketleri:}

Meşrutiyetin ilanından sonra Ermeni Komitalarının hareketleri bir süre durulmuş gibi göründü. Komite başkanları etkinliklerini yasal çerçevede ve meşrutiyetin korunması için sürdürecekleri yolunda beyanlar veriyorlard ${ }^{16}$. Bu konuda Taşnaksutyun - Ittihat ve Terakki arasında bir antlaşma yapılmışsa da, Taşnaksutyun'un yayın organı olan Truşak Gazetesi yeni rejimden memnun olmadıklan yolunda sürekli yayınlar yapıyordu ${ }^{17}$.

1. Dünya Savaşı öncesi Ermeniler sıkı bir şekilde orgütlenmişler ve çok sayıda silah depo etmişlerdi. Bu aşamada Ermeniler, Osmanlı Imparatorluğu ile Rusya arasındaki olası bir savaşta hangi tarafta yer alınması gerektiğini belirtmek için toplantular yapıyorlardı. Istanbul'da Birleşik Millî Ermeni Komitesi savaşıa Ermenilerin Osmanlıya sadık kalacaklan ve dış tahriklere kapılmayacakları yolunda karar aldı. Bundan amaç Osmanlı Imparatorluğu'nun güvenini kazanmaktu.

1914 yılının Haziranında Taşnaksutyun Kongresi Erzurum'da toplandı. Bu toplantuda da fttihat ve Terakki Hükümetinin islahatlarının gőstermelik olduğu, bu nedenle muhalif kalınacă̆ı, hükümetin siyasi proğramının eleştirileceği ve tutumuyla mücadele edileceği yolunda kararlar alındı ${ }^{18}$. Ermeniler bu tür faaliyetlerde bulunurken Osmanlı Imparatorluğu 1. Dünya Savaşı'nın eşiğindeydi.

\section{Birinci Dünya Savaşında Ermeniler.}

Birinci Dünya Savaşı başladığında, Ermeni Komiteleri ve Patrikane Osmanlı Imparatorluğu savaşa katulırsa izliyeceğgi politikayı saptamak için Galata'daki Ermeni Büyuik Merkez Okulu'nda biraraya geldiler. Burada Ermenilere, "Osmanlı Hükümetine sadık kalmalan, askeri görevlerini yapmalan, dış etkilere kapılmamalan" telkin edildi ${ }^{19}$.

Osmanlı Imparatorluğu 1 Kasım 1914'de 1. Dünya Savaşı'na kauldı. 3 Ağustos 1914'de zaten seferberlik ilân edilmişti. Seferberliğin ilânı üzerine birçok Ermeni Rusya ve Iran'a sı̌̆ındı. Bu sıralar Ermeniler düşmanla sıkı bir işbirlił̆i içindeydiler. Erzurum, Trabzon, Bitlis Van gibi çatışma çıkma olasılığı olan bölgelerdeki Ermeniler silahlandılar. Ermeniler silah altına alınmayı reddeutiler, alınanlar da silahlanyla birlikte kaçtılar. 1914 Ağustos'unda gazetelerde çıkan beyanlarda Ermenilerin Ruslara karşı savaşmaması, Rusya'nın yanında yer alması bildiriliyordu20. Zeytun'lu Ermeniler Osmanlı bayrağı alunda bulunmayı reddederek, kendi ordulannı kurarak bolgelerini savunmak istediler. Istedikleri kabul edilmeyen Ermeniler isyan ederek sivil halka ve

16 SAKARYA, I., age. s. 146.

17 URAS, E., age. s. 578.; MAZICI, N., age. s. 33.

18 SAKARYA, I.,age. s. 1687.

19 OKE. M. K., Ermeni Meselesi, Istanbul 1986, s. 123.

${ }^{20}$ GURUN, K., age. s. 198. 
jandarmaya saldurilar düzenlediler. 1915 yilında Maras'tan Zeytun'a cephane ve asker getiren bir konvoya kaldırarak 6 erimizi şehit ettiler. Zeytun bolgesindeki Ermeni isyanı tehcir karanna kadar devam etti.

\section{Tehcir Kararı.}

Osmanlı Imparatorluğu'nun cephede savaşı̆̆ı đüşman yeumiyormuş gibi birde ülke içindeki Ermeni isyanlanıla uğraşıyordu. Hükümet Patrikaneyi defalarca uyararak, "bu durumun boyle devam edip gitmesinin olanaksız olduğunu, gúvenliği sağlamak için gerekirse zor kullanılacağını" bildirdi. Hükümetin bu iyi niyetli ve içten uyanılanna patrikhane hiçbir zaman olumlu cevap vermemiştir, hatâ çeteleri daha da kışkırtmıştur.

Ermeni komitelerin faaliyetleri ve isyanlar büyük boyutlara ulaşmışt. 24 Nisan 1915 (11 Nisan 1331) tarihinde Dahiliye Nezaretince Ermeni Komite merkezlerinin kapatılması, elebaşılarının tutuklanması ve her türlü belgelerine el konulması kararı alındı. Bu karar üzerine devlet aleyhine faaliyette bulunmak suçundan Istanbul'da 2345 Ermeni tutuklanmıştır ${ }^{21}$. Ermenilerin her yil "Soykinm"iddialarıyla kutladıklan 24 Nisan günü bu emrin yayınlandığı gündür. Bu karardan sonra Ermeni mezalimi azalacak yerde daha da arımışur. Bu durumda hükümet, onlem almak zorunluluğunu duydu. Gerekli görülecek tehlikeli kişilerin, toplu halde veya ferden, başka bölgelere zorunlu olarak gönderilmesi veya gö̧ etmesi sağlanacaktı. Tehcir (göç) kanunu bu gaye ile çıkanımıştır. Tehcir Kanunu 14 Mayıs 1915'deyürürlüğe girmiştir ${ }^{22}$. Kanun, seferde halk tarafından herhangi bir şekilde hükümet emirlerine, vatan savunması ve güvenliłginin korunması ile ilgili icraata karşı gelenlerin ve silahlı saldında bulunanlann yetkililerce savaş bőlgesi dışına nakledilebilmelerini düzenliyordu. Kanun, sadece Ermenilere uygulanmak için çıkartulmamışur, kanun metninde bir tek "Ermeni" sőzcügü de yoktur. Kanun, sayılan suçları işleyen ve yine sayılan davranışlarda bulunanlar için çıkartulmı̨̧tr. Mecburi gợ, ülkenin bütün kesiminde uygulanmamışur. Ełger kanun, Ermenilerin iddia ettikleri gibi Anadolu'daki tüm Ermenilere uygulansaydı Tehcir Kanunu'ndan sonraki olaylar olmazd.

Tehcirin nasıl yapılacağı konusunda Bakanlar Kurulu kararlar almısur. Buna gore; Halk kendilerine ayrılan bölgeye rahat bir şekilde, mal ve can güvenliği sağlanarak nakledilecektir. Yeni yerlerinde $\mathrm{ev}$, arazi verilecek, ihtiyacı olanlara hükümetçe mesken inşa edilecek, çifţ̧i ve zenaat erbabına tohumluk ve âlet, edavat sağlanacakur. Ermeni halk taşınabilir mallanıı yanlanında götürebilecek, gayrimenkulleri ise açık arturmayla saularak paraları kendilerine odenecektir. Gayrimenkulleri satmaktan amaç Ermenilerin ayrıldıklan yerlerle ilişkilerini kesmektir ${ }^{23}$. Osmanlı Imparatorluğu savaşan subaylannın maaşlannı ödeyemezken Ermeni halkın rahaţ̧a nakli için elinden geleni yapmış, her türlü olană̆ı sağlamışur.

21 SAKARYA,1., age. s. 224.; EROGLLU,H., Turk Inkılap Tarihi, Istanbul 1982, s. 225.

${ }^{22}$ HOCAOGLU,M., ArşivVesikalarıyla Tarihte Ermeni Mezalimi ve Ermeniler, Istanbul, 1976. s. 648.; "Tehcir Kanunu"nun içerdiğgi maddeler hakkunda genił bilgi için bł. MAZICI,N., age. s. $77 \mathrm{vd.}$

${ }^{23}$ GURON,K., age.s. 216-217. 
Tehcirden sonra da Ermeni isyan hareketleri durmamıștr. 5 Haziran 1915'de Hamparsun Boyacıyan isimli Ermeni çetecinin başkanlığında bir çete Doğu cephesinin ikmal yolu olan Şebinkarahisar'ı basmış, yakıp yıkmış ve birçok insan oldürmüşlerdir ${ }^{24}$.

Oteden beri Osmanhı hükümetine sorun olan Zeytun halkı bu tutumunu Tehcir kararının uygulanmasında da sürdürdüler. Ermeni çeteciler dağlık araziye dağılarak Türk koylerine ve askeri birliklere saldınlara giriştiler. 1915 Temmuz'unda Maraş ile Bahçe kasabası arasında Fındıkçık kðyünde çok sayıda Ermeni çeteci toplandı, burayı ayaklanmanın merkezi olarak seçtiler. Çevredeki Ermeni koylerinden çok miktarda yiyecek ve mühimmat temin edip stok ettiler. Isyan bölgesine gonderilen Jandarma müfrezesi yeterli olmadı, çevreden yeni kuvvet takviyesi yapılarak 15 saatlik bir çarpişmadan sonra isyan basurild.

\section{Sevr Antlaşması.}

Istanbul Hükümeti 10 Ağustos 1920 tarihinde itilaf devletleriyle Sevr Barı̧ Antlaşması'nı imzaladı. Bu antlaşmaya göre; Ermeniler bağımsız bir devlet olarak Osmanlı Hükümetince tanınıyor ve Ermenilere geniş bir arazi veriliyordu.

Erzurum, Trabzon, Bitlis ve Van illerinde Türkiye ile Ermeniler arasındaki sınınn tespiti A.B.D. Başkanının hakemliğine bırakılıyordu. Aynca bu sınırlara bitişik bütün Osmanlı topraklarının askersizleştirileceği konusunda verilecek bir kararı da diğer sőzleşmeci devletlerle birlikte Osmanlı Imparatorluğu da kabul edecekti ${ }^{25}$.

Istanbul hükümeti bu antlaşmayla birlikte adeta kendi olüm fermanını imzalamıştı. Anakara'daki ulusal Hükümet Sevr Antlaşması'nı hiçbir zaman kabul etmedi. Istese Istanbul Hükümeti de kabul etmezdi. Zaten ülke içine düşebileceği en kơtü duruma düşmüştü, bundan daha kơtä duruma düşemezdi. Bu konuda VILLALTA, gorrüşlerini şu şekilde belitmektedir: "...10 Ağustos 1920 tarihinde, Osmanlı Hükümetinin temsilcileri adına Sevr Antlaşması denen ve eski Doğu Sorununu kimsenin tasavvur edemiyeceği bir şekilde sona erdiren antlaşmaya imzalannı attular. Sevr, sadece Imparatorluğu paramparça etmekle yetinmiyor, halkının çoğu Türklerden oluştuğu için Vilson prensiplerine göre Türk kalması gereken Anadolu'yu da parçalara bolüyordu. Şoyle ki: Doğu illerinde, Ingiliz himayesi altında bağımsız bir Ermenistan ve muhtar bir Kürtdistan yaratulıyordu. Suriye ile olan güney hudut Urfa kentinin kuzeyinden geçirilerek Türk topraklanndan büyü̈k bir parça kopanlmıs oluyordu"26.

${ }^{24} \mathrm{Bu}$ konuda, Ermenilerin yaptıklan mezalimi gordưgunu belirten 90 yaşındaki bir vatundaşımızın hatıralan 4.3.1987 tarihli Türkiye Gazetesi'nde yayınlanmışur: "Ermeniler Kasap Gibiydi*. s. 1 ve 9.: Ermeni isyanlanı hakkında geniş bilgi i̧̧in Bk. ETHEMOĞLU, M., age. s. 21-32.; EROGLU, v. age. s. 57-98.; MAZiCI.N., age. s. 3450.

${ }^{25}$ GURUN,K., age. s. 252.; EROGULU,H., age.s. 212. vd.; KOÇU, R.E., Osmanlı Muahedeleri ve Kapitulasyonlar, 1300-1920., Istanbul 1934, s. 274.

${ }^{26}$ VILlALTA. J.B., Ataturk, T.T.K.Y., Ankara, 1982, s. 251. (ingilizce);i Keza aynı muellifin bu eseri Kultur vce Turizm Bakanlığb tarafindan 1982 yilunda Turkçe'ye gevrilmiştir.; Bemard LEWIS de Sevr Antlaşması konusunda goruşlerini şu şekilde ifade etmektedir.: "...Sevres andlasmasıpek insafsızdı ve Türkiye'yi, en zengin illerini ilhak eden devletlerin ve uluslann insafina dayanarak yasayabilecek, çaresiz, köturam ve gölge bir devlet halinde bırakacaktı. Yenilmiş Almanya'ya empoze edilenden çok daha ağırdı ve 
1920 yılı sonlarında Doğu Cephesindeki Türk Kuvvetlerinin başanlı olmalan üzerine Milletler Cemiyeti'nin Ingiliz Temsilcisi, Ermenilerin kơtüleşen durumunun düzeltilmesi için bir onerge verdi ve genel kurulu toplantaya çă̛ưdı ${ }^{27}$.

\section{Lozan Konferansı.}

27 Şubat 1921'de Isviçre'nin Lozan şehrinde konferans başladı. Ermeni delegeler Sevr Antlaşması'nın yürürlükte kalması yolunda çalışıyorlardı. Fakat pek başarılı olamadılar. Sevr Antlaşmasi'ndaki, "Bağımsız Ermenistan" ibaresinin yerini burda belirsiz "ocak"kavramı alıyordu. 21 Eylül'de, bu ocağın Türkiye'den ayrı ve bağımsız olması karan alındı. 28 .

Bat cephesinde 26 Ağustos 1922 'de başlayıp 30 Ağustos 1922 'de biten ve Yunanlılar'ın denize dరkülmesiyle sonuçlanan Büyük Taarruz'dan sonra 11 Ekim 1922 tarihinde Mudanya Mütarekesi imzalandı. Bunun üzerine Türkiye Cumhuriyeti Hükümeti 28 Ekim 1922'de Lozan'da yapılan toplantıya çağrıldı. Konferansta azınlıklarla ilgili kanunlar da görüşülecekti. Ermeniler Lozan Konferansi'na kendilerinin de alınması yolunda çok çaba gősterdiler. Bunun için birçok devlet başkanına başvurdular veya mektuplar yollaḍılar, ama başanlı olamadılar.

Ermeniler Konferasta azınlıklar kısmında görüşüldü ve Lozan BAnş Konferası'nda ayrıca Ermenilerden söz edildi. Lozan Konferansı'nda umduklarını bulamıyan Ermeniler Konferanstan aynlırken Konferansa katulanlara bir bildiri verdiler. Bu bildirinin bir yerinde ; "...Ermeni sorununun çozümlenmemiş olarak kalmasının Ermenilerin durumunu daha kơtü bir hâle getirmiş olduğunu gőzönüne koymak isteriz. Bụyúk devletler Türkiye'deki Ermenilerin kurtanlmalan hakkında yalnız siyasi ve insani açıdan değil, Ermenilerin Birinci Dünya Savaşı'nda itilâf Devletleri için ve bu devletlere karş̣ göstermiş olduğu pek çok hizmelerden ơtürü verdikleri sőzleri de haurlaunz....29 denilmektedir. Burada Ermeniler kendilerinin büyük devletlerce bir maşa olarak kullanıldığını iddia etmektedirler.

Türkiye de bir ulusal yas günüyle karşılandı”. Bk. LEWIS, B. Modem Türkiye'nin Dợu̧̧u, Ankara 1970, s. 247.; Keza aynı eserin 1984 basımında da aynı sahife.; Sevr Antlą̧ması'nın geniş anlatımı içn Bk. EROĞLU, H., age. s. 210-213.; Ataturk. Genelkurmay Askeri Tarih ve Stratejik Etüt Başkanlığıı Yayını, Ankara, 1980, s. 183.; KINROSS, L. Atatük. Bir Milletin Yeniden Doğuşu. Sander Yayınlan, Istanbul,Haziran 1984, s. 355 vd. Sevr Antlaşmasinın Ermenileri ilgilendiren maddelerinin açıklaması için Bk. MAZICI, N., age. s. 105.

${ }^{27}$ GURUN, K. age. s: 255 vd.; Sevr antlą̧ması hakkında geni bilgi için Bk. SHAW. S.J.SHAW, E.K.. Osmanlı Imparatorluğu ve Modern Türkiye, (1808-1975). II. Cilc. Istanbul 1983, s. 423 vd.; EROGLUU, H., Turk Devrim Tarihi, Ankara 1972, s. 136-139.; Osmani Imparatorluğunun 1920 ve daha sònraki yıllardaki durumu için Bk. GOZE, A., Inkilâp

Tarihimi ve Atatürk 1lkeleri. Istanbul, 1984, s. 105-175.; GOYONÇ, N., Osmanlı Idaresinde Ermeniler, Istanbul 1983. s. 41.

${ }^{28}$ SAKARYA,1., age. s. 423.; Lozanda Ermeni Meselesi hakkında geniş bilgi için BL. ETHEMOCLU,M., age. 3. 46-47.

${ }^{29}$ URAS,E., age. s. 742. 
1960'lı yllarda Ermeniler dünya kamuoyunu kendi taraflanna çekmek için bir çok etkinliklere giriş̧tiler. 24 Nisan gününü "Soykırım" günü olarak ortaya attular. Bu tarihlerde çıkan çeşitli gazetelerde ve dergilerde Van, Bitlis, Ardahan, Erzurum, Trabzon ve Kars Türkler'in Ermenilerden gasp ettikleri topraklar olarak gösterildi ${ }^{30}$. Tiyatrolarda Ermeni konulu oyunlar oynandi. Beyrut'ta, Fransa'da gossteriler, mitingler düzenlendi. 1969 yılının 24-26 Nisan tarihlerinde Londra'da Büyükelçiliğimiz onünde gosteriler düzenlendi, doğu illerimizin Ermenilere verilmesi istendi. 1970'li yıllardan sonra Büyükelçiliklerimize saldırıldığını, Türk Hava Yolları bürolarının basıldığını gormekteyiz. Yine bu yıllardan itibaren diplamotlarımızı hedef alan saldırılara başlandığını görmekteyiz. 1970'li yılların ortalarından itibaren bu hareketlerin yerini ơgü̈lü Ermeni terörüne bıraktığını ve yoğunluk kazandığını müşahade etmekteyiz.

Halen başta faaliyet merkezi durumunda olan Lübnan ile Fransa, Yunanistan ve Amerika olmak üzere diğer bazı Avrupa ve Ortadoğu ülkelerinde Ermeni faaliyetleri sürmektedir.

Bugün Ermeni faaliyetlerini; hedefleri aynı, fakat metodları değişik gơrünen üç ana orgüt yürütmektedir:

Sözümona Ermenistan'in Kurtuluşu için Ermeni Gizli Ordusu (ASALA), ilk defa 1975'de duyulmuş, Marksist-Leninist ideolojiyi kabul eden bir ơrgüttür. Amaçlarını; işgal altandaki Ermeni tapraklarını kurtarmak, birleşik, demokratik ve Sosyalist bir Ermenistan kurmak, "soykırım"ın Türkiye tarafından kabul edilmesini sağlamak ve

${ }^{30}$ Almanya'da yayınlanan "Geo" Dergisi yazaralarından Wolfgang SCHRAPS'ın, "Kaybolmus Bir Halkı Ararken" isimli makalesinde aynen şöyle denmektedir: "...Ermenilerden geriye kalan kültür eserlerini saptamak için aylarca çalışmak gerektiği söylenir. Birkaç hafta içinde bu izleri bulmak için yapılan çalı̧̧malar, meselâ aynıadı taşıyan gölün yanında $1720 \mathrm{~m}$. irtifadaki $V$ an şehrinde olduğu gibi, gerçek bir depresyonla sonlanır. 1915 yılına kadar nüfusunun \%42'si Ermenilerden oluşan Van şehri bu kaybolan halkın en önemli ekonomik ve sosyal merkezlerinden birisi idi. Şehir birinci Dunya Savaşı içindeki, bu Ermenilerin sonunu getirmiştir. Tamamen tahrip edilmiş ve sonra yeniden kurulmuştur Van'ın Güneydoğusundaki Varakvang manastırı ve onun meşhur kitaplığı eski seyehatnamelerde anlatılmaktadır. Bugün bu manastırı arayanlar, onun olduğuyerde yedi kilise adındaki kürt kboyünú bulurlar. Bundan geri kalanları, tıpkı Manaker kilisesinin yemişlik köya için kullanıldığı gibi, diğer kơyluler de evlerini korumak için kullanmışlardır". Bk. GEO, Mart 1986, s. 113. Yazann söz konusu makalesi gerçekleri aksettirmemesi nedeniyle tenkide şayandır. Şઠyle ki, Ermeniler, Doğu Anadolu'da yaşamıs oldukları topraklar uzerinde genellikle Turk Toplumu ile hemen her yơnden kaynaşmış ve rahat bir yaşam tarzı surdürmaşler ve hiçbir zaman birlikte yaşadıkları Türk Toplumu içinde çoğunluğu oluşturmamışlardır. Yazarın sözde katliam ile ilgili iddiası tehcir kararı ile $1.500 .000^{\prime}$ a yakın Ermeni'nin katledildiği yolundaki mesnetsiz görü̧şlere bir temel kazandırabilmek için ortaya atılmuştır. Zira Van şehri içinde \%42'lik bir Ermeni topluluğunun varlığını varsaymak, sözde katliam iddialarında ortaya atılan abartılı rakamları da bir yerde doğrulamak olacaktır. Nitekim yazarın kasıtlıolarak bunu vurgulamak istediği de apaçık ortadadır. Evet, bir toplum olarak Ermenilerde kendi kultürrlerini yaratmışlar ve bunun doğal bir sonucu olarak da çeşitli eserler vucuda getirmişlerdir. Ancak şurası bilinmelidir ki Anadolu'da hiçbir zaman bağımsız bir Ermeni DEvleti kurulmamışııı. Bu açıdan Alman yazarın Ermeni kultưrunu incelerken samimi olmadı̆̆ı̆ tarihsel gerçekleri objektif olarak yansttmadığı onları saptırdığı kanaatindeyiz. 
Türkiye'ye tazminat odetmek, şeklinde ifade etmektedirler ${ }^{31}$. Bu ơrgütün Kürdistan tş̧i Partisi (PKK) ile de işbirlił̧i yapư̆ (JCAG): sőzde Ermenilere karşı yapılmı ve halen de cezasız kalan katliamın intikamını almak, Ermenilerin uğradıkları haksızlıkları gidermek ve Türkiye'nin 1920 Sevr Antaşması'na göre, "Ermeni topraklarını" kendilerine iade etmesini sağlamak amacındadurlar.

Yeni Ermeni Direnişi (NAR); Asala ile ortak eylemlere giren sol taraflı bir orgüttür. 1977 yılında ơrgütün ismi ilk defa duyulmuştur.

Halen, benimsedikleri farklı fikir ve amaçlarla faaliyetlerini yürütmekte olan ụ̈ Ermeni partisi bulunmaktadır. Bunlardan Hınçak, Türkiye'den kopanlacak topraklann Sovyet Ermenistanı'na iltihakını; Taşnak, Türkiye'den koparilecak topraklarla Sovyet Ermenistanı'nı birleştirerek müstakil bir Ermenistan kurmayı; Ramgawar ise, sosyal ve kültürel sorunlara eğilerek Ermeniliğin bekasını sağlamayı amaçlamaktadırlar. Bu bahsedilen orgütler ile bu partilerin ilişkileri kesin olmamakla birlikte, istekleri itibariyle, Asala ile Nar örgütlerinin Hınçak; Jcag orgütünün Taşnak Paritileri paralelinde olduklan bilinmektedir. Aynca batı yanlısı olarak bilinen Taşnak ile, nottr olarak bilinen Ramgawar, Fransa-Kanada ve ABD'de kamuoyu oluşturma faaliyetlerine devam etmektedirler.

Son yıllarda, bilhassa son 5 yıl içinde, uzun yıllar üzerinde hiç konuşulmamıs bir "soykırım" meselesi ortaya atılmıştır. Soykırımın 1915 yılında yapıldığını iddia etmektedirler. Yani aradan yetmiş yıldan fazla bir zaman geçmiştir. Bu geşen zaman içinde konuyu gündeme getiren bir kınama yapılmış değildir. $O$ zaman insanın aklına §̧oyle bir soru geliyor, Bu soykınm yeni mi duyuluyor? Tabiki bunlann hepsi sonradan ortaya atulan ve hiçbir gerçeği ifade etmiyen sözlerdir.

Osmanlı Imparatorluğu'nun her yanından kuşauldığı bir zamanda, bir de Ermeni azınlığın başkaldırması üzerine, bụ toplumun alınan kararla savaş boligelerinden

${ }^{31}$ GURON, K., Ermeni Terörizminin Sebepleri ve Mucadele Yollan, Uluslararası Terórizm Sempozyumu, s. 245.; "GEO" Dergisi yazarı SCHRAPS, geçen bahislerde belirttigimiz makalesinde Asala ile ilgili göruşlerini şu şekilde değerlendirmektedir: "...Asala, şimdiye kadarki çok sayıda terör askiyonları ile 58 Turk diplomatını katlederek. Turkiye hudutlarındaki eski Ermenistanı yeniden ele geçirmek yönundeki kararını ortaya koymaktadır Eylemcilerin fiilleri. 1979 yılında Paris'te toplanan "Ermeni Danya Kongresi"nin hedef ve kararlarına paralellik arzetmektedir. Tipkı yahudilerin Israil'e dönmeleri gibi, dưnyadaki bütün Ermeniler, babalarının vatanlarına dơnmelerini sağlamak istiyorlardı. ...Bununla beraber bir yandan doğrudan gelen Humeyni'ci fanatik islâm akımı öteden Asala'nın her suikast eylemi Ermenileri haftalar süren endişe ve huzursuzluğa itmektedir.. Eğer Istanbul'daki Ermeniler bugan birşeyden korkuyorlarsa, o da Asala'nun terör eylemleridir. Bk. "GEO" Mart 1986, s. 103-119. Yazar Asala'nun hareketlerinden söz ederken, Asala'yı Ermeni dünya Kongresi sonucunda oluşan meşru bir orgut olarak tanımlamakta ve Ermeni hareketine Israil benzeri bir nitelik vermek istemektedir. Bu da açıca terörizmin desteklenmesinden baska birşey değildir. Bugan rahatça kendi dilinde ilk oğretimini yapan, kendi dilinde gazetesini çukaran, kiliselerinde ibadetini yapan ve büton Anayasal hakları rahatça kullanan bir Ermeni toplumunun varlı̆̆ıı rağmen. Türkiye dı̧̧ında yaratılmak istenen olumsuz imaj ile Turkiye azerinde donya ulkelerinin bu yöndeki baskılarını arttırmak. Ermeni terơrizmine meşrutiyet kazandirilmak istenmektedir. 
1

uzaklaştınılması ve başka bölgelerde yerleştirilmelerinin bir soykınmla ilgisi olamaz. Aynca iskân sırasında Osmanlı Imparatorluğu'nca bu toplumun kılına zarar gelmemesi için ozel ozen sarfedilmişti ${ }^{32}$. Aynca bir toplumun savaş bölgelerindenuzaklaşturılarak, başka boblgelere nakledilmelerinin ve iskân edilmelerinin, Devletler Hukuku'nda yeri olan ve gerektiği zamanlarda devletlerin uyguladığı bir yol olduğu bilinmektedir.

Osmanlı Devleti'nin genişleme dơneminde işgal ettił̧i topraklar üzerinde bir Ermeni Devleti kurulmadığ, herkesce bilinen bir gerçektir ${ }^{33}$.

Iște, Ermeniler vatanlarına el konulduğu, kendilerine bir soykırım yapıldı̨̆gı hususlarını bahane ederek bölücülük faaliyetlerine başlamışlardır. Bugünkü Ermeni terörizminin ilk ơncüsü, 1920'lerde, Batı Avrupa'da sürgünde yaşayan birçok eski Osmanlı yetkilisine suikast düzenliyen "Nemesis" adlı bir Taşnak alt orgütüdür. Bu teröristlerden birinin söyledił̌ine göre Taşnaklar, 1919'da Istanbul'da yayınlanan Jagadamard adì bir Ermeni gazetesinin binasında faaliyet gösteren bir "Suikast Sorumlu Bürosu"'kurmuşlardır 34 .

1920'li yıllarda başlayan Ermeni Terörü; günümüze kadar devam etmiş ve etmektedir. Ermeni terơristler son yıllarda Türk toprakları üzerinde de eylem gerçekleştirerek Ankara Esenboğa Havaalaninda 9 kişiyi óldürmüşlerdir. 7 Ağustos 1982 tarihinde gerçekleştirdikleri bu eylem sırasında 72 kişi de yaralanmıştır. Yakalanan teröristlerden birisi olan Levon Ekmekçiyan'a eylemle ilgili olarak sorulan soru üzerine verdił̣̌i cevapta olenleri kastederek "Bu yeterli değgil" demiştir. Yine silahlı saldırganlandan

32TOROS,T., Ermeni Tehciri Meselesi, Hayat Tarih Mecmuas, 1 Ocak 1970. Yil 5, Cilt 2. Say1 12, s. 64-71.

${ }^{33}$ Turkiye Gazetesi'nin 4.3.1987 tarihli nüshasında yer alan haber ફ̧రyle: "XVII. yüzyılda yaşamıs tarihçi ve ilim adamımız Kâtip Celebi'den Ermeni pionlara mesaj. Anadolu'da Ermeni Devleti kurulmadi. Anadolu coğrafyasından Ermenistan kavramını silen ilk Turk ilim adamının Kâtip Çelebi olduğu ortaya çıkarıldı. Tarihçi Cezmi Yurtsever, Kâtip Çelebi, batılı coğrafyacıların Anadolu üzerinde Ermenistan bölgesinin varlığını gőstermelerine ilmen itiraz etmiştir. Tarih araştırmacısı Cezmi Yurtsever Anadolu Coğrafyasından Ermenistan kavraminı silen ilk Türk ilim adamının Kâtip Celebi olduğunu sőyledi. Istanbul Süleymaniye ve Topkapı Sarayı Kütuphanesi'nde Kâtip Çelebi'nin Cihanntımâ isimli coğrafya kitabı ve kaynaklan üzerinde araşurme yapan Cezmi Yurtsever, 15 ve 16. yazyıllarda batı dünyasında bulyuk coğrafi keşifleri yapan seyyahların hemen hepsinin peşinen Anadolu uzerinde Ermenistan bolgesi gosterdiklerini, ancak batı Hristiyan dünyasının bu iddialarına karşı sistemli ve ilmî tenkidi Kâtip Celebi'nin yapıı̆ını açıklayarak şöyle dedi: "Kristof Kolomb. Magellan, Merkator gibi batılı coğrafyacıların, Yunanlı coğrafyacı Pıolema'nın eserini taklit ederek Anadolu uzerinde Ermenistan Bölgesi göstermelerinin hatalı olduğunu Kâtip Celebi, Cihannüma'sında geniş olarak açıklamıştır. Ayrıca Mıgırdıç Galotavi isimli bir Ermeni coğrafyacıya Anadolu'nun Ahmed El Kırmi'yede. Kafkasya haritasını çizdirerek, o bölgelerde Ermeni bulunmadığını gostermiş ve bu haritalanı eserine koymuştur. Ermenistan diye bir Devlet kurulmadığını, yaklaşık 10 yıl devam eden Doğu Anadolu gezileri esnasında oğrendiği bilgiler ve on bin kitap ile onbeşbin risalenen değerlendirilmesi sonucu açıklayabilmiştir".

${ }^{34}$ ShIRAgAN,A., The Legacy: Memoirs of an Armenian Patroit, Boston, Hairenik Press, 1976, s. 37. 
biri 1915'de Ermenilerin Türkler tarafından katli olayın kastederek "Bizden bir milyondan fazla öldü. Sizden 25 kişi olse ne farkeder? ${ }^{\text {"35 }}$ diye bağırmışur.

Gorrüldügü gibi Ermeniler daha doğnusu Ermeni terơristler tek taraflı ve asılsız iddialarla sozzümona Türk Milletinden hesap sormak istemektedirler. Kısaca tarihi geçmişini ठzetlediğimiz Ermeni topluluğunun bugüne kadar hiçbir zaman bir devlet oluşturmadığı kesinlikle bellidir. Bugưn halâ ülkemize karşı büyük bir kin dalgası, dış ülkelerde bulunan Emeniler tarafindan sürdürülmektedir.

Oysa bizim bugün yurdumuzda bulunan Ermeni vatandaşlanmız, hayatlanndan memnundur. Işlerine güven içinde devam etmekte, bu çeşit yayın ve saldınlardan da rahatsız olmakta, uzüntil duymaktadırlar.

Türkiye Cumhuriyeti'nin, ülkesi ve milletiyle bolünmez bir bätün oldư̆u, ullkenin ve milletin bütúnlügưunú boblünmezližini içten ve diştan bozmaya çalışan faaliyetlere karşı en ağır cezanın uygulanacağı bilinmelidir.

${ }^{35}$ Olayın faillerinden Ermeni asıllıLevon Ekmekçiyan yapılan yargılaması surasında Askeri Savcilikta: "Ben Ermeniyim. Asala Orgütu'ndenim. Halen Turkiye Cumhuriyeti Devleti'nin sınurlan içinde bulunan Kars, Ardahan, Erzurum, Erzincan. Mų̧, Van ve Turkçe adını hatırlayamedığım Sasun adındaki illerin bulunduğu topraklar Ermeni topraklarıdır, bizi 1915 senesinde bu topraklardan çkarmıłlar ve birbuçuk milyon Ermeniyi kesmişler. Benim mensup olduğum Asala orgựil yukanda belirtuiğion copraklan geri almak için kurulmuştur. Beni de vatanım için Tükiye'ye olmeye gönderdiler" demiştir. Levon Ekmekçiyan duruşma oncesi mahkeme heyetine hitaben yazdıŏı dilekçesinde §̧రyle demektedir: "...Ne yazık ki ben bütun hayaum boyunca bize anlatılan sahte sözlere ve yalan talihe inanmışım. Bugün bizim vatanın kurtanlmasının ismi altunda çalışan bu örgütlerin, eskiden bizim başımızda olan Taşnaklarla hiçbir farkının olmadığını, yeni uyanan gerçeklerle ve şimdi hissettiklerimle ispat etim. ...Bize doşman edilen Türklerle ben 30 gün yaşadum. Ve gördüm ki bizim düşmanımız Tărk değildir, bizim düşmanımızbizim büyưklerimiz ve bizim tarihleri yazanlardır. Buna inanun ve bu yalnı§ yoldan ellerinizi çekin ve sizi seven iyi olmanızı isteyen Tük halka ile kardeşe yą̧ayın..." Bknz. Esenboğa Baskını Davası, Ankara Synt. K.lığı Askeri Mahkemesinin 1982/296 E., 1982/282 K. sayllı Gerekçeli Hükmü, Karar Tarihi 7.9.1982, s. 7 ve 9. Ayrıca Bk. GUNTER, M.M., Ermeni Terörizminin Çă̆daş Gơrunümü, (Uluslararası Terörizm Sempozyumu) s. 105. 